\title{
Globalisation and Court Practice in Iceland: New Case Law of the Supreme Court in Relation to the EEA Agreement and European Convention on Human Rights
}

\section{Halldóra Thorsteinsdóttir}

\begin{abstract}
This article examines the status of international treaties in Iceland law and how Icelandic court practice has developed in recent years in that area. With regard to the relationship between domestic law and international law, Iceland adheres to the principle of dualism. This means that international law does not come into force as Icelandic law unless implemented by the legislator. As a result, Icelandic Courts will not, in general, apply provisions of international treaties unless they have been incorporated into Icelandic statutory law. However, this does not mean that international obligation are not fulfilled, as Icelandic Courts will seek to interpret domestic law in line with international obligation to the extent possible. If an international treaty has been implemented into Icelandic law, its provisions are binding like other domestic law. With regard to the EEA Agreement, Icelandic Courts will seek to interpret national law in accordance with EEA obligations and follow the judgments of the EFTA Court if the Icelandic provision in question is open to such an interpretation. With regard to the European Convention on Human Rights, Icelandic Courts will even go a step further, as recent judgments show that Icelandic Courts tend to interpret the human rights provisions of the Icelandic Constitution in line with interpretation laid down by The European Court of Human Rights, even in cases where such an interpretation does not exactly fit within the direct wording of the provision in question. This is due to a special connection between the human rights chapter of the Icelandic Constitution and the Convention, as one of the legislators' main goals when amending the Constitution in 1994 was to bring the human rights chapter more in line with the Convention.
\end{abstract}

H. Thorsteinsdóttir $(\bowtie)$

Department of Law, Reykjavik University, Menntavegur 1, 101 Reykjavik, Iceland

e-mail: halldorath@ru.is 


\section{Introduction}

Like other Nordic countries, the Icelandic legal system has experienced rapid changes due to the development of international law in recent years, and an increasingly large proportion of national law is rooted in international agreements the Icelandic state has signed. Icelandic Courts have also been subject to these changes and have had to answer questions regarding the relation between domestic law and international law and the effects of international treaties when interpreting Icelandic statutory law.

The aim of this article is to shed light on the impact of the most important international treaties Iceland has signed on the Supreme Court's case law in recent years. Emphasis will be placed on the European Convention on Human Rights (ECHR) and the EEA Agreement, as these are undoubtedly the international agreements that have had most impact on the Icelandic legal system in recent years.

\section{The Status of International Law in Iceland}

With regard to the relation between domestic law and international law, Iceland adheres to the principle of dualism. Ratified international treaties therefore do not assume the force of domestic law, as they are only binding according to international law. ${ }^{1}$ In other words, domestic law and international law are two separate legal systems, and the rules of international law will not be part of national law without being implemented into national law by the Icelandic Parliament. ${ }^{2}$ As a result, individuals and legal persons are unable to invoke directly the international provisions before Icelandic courts. This is in contrast to monistic systems, where international law is seen as an integral part of the national legal system and indeed often prevails in the event of conflict between international law and national law. ${ }^{3}$ On the other hand, following the transformation of international legislation into domestic law, international provisions are no longer considered international law in the application of the legislation on the domestic level and will be applied equally to domestic law.

Looking at court practice in Iceland, where international law has been referred to or applied, it is clear that there are many examples of judgments where the courts, by reference to the principle of dualism, have refused to give effect to unincorporated treaties. An example is Case No. 23/1974 of 18 June 1975, which went to trial before the ECHR became a part of domestic law. The case was about lawsuit filed by E against the city of Reykjavík on the grounds that regulations prohibiting him from keeping a dog were contrary to Article 8 of the ECHR. The Supreme Court of Iceland held that the rules in question were not to be disregarded on the grounds that they

\footnotetext{
${ }^{1}$ Tryggvadóttir and Ingadóttir: Online article: https://www.nyulawglobal.org/globalex/Iceland1. html.

${ }^{2}$ Björgvinsson (2014), p. 26.

${ }^{3}$ Wallace (2005), p. 37.
} 
were contrary to the aforementioned Article, but also pointed out that the Convention had not acquired the status of law in Iceland. ${ }^{4}$

Another example is Case No. 77/1985 of 25 November 1985. The case concerned Mr. Kristinsson conviction for a traffic offence by a district criminal court where the deputy judge who heard the case was also a deputy chief of police. Before the Supreme Court, the defendant, claimed that the judgment should be annulled on the grounds that a judge that else served as a chief of police could not be impartial. He maintained that the double role exercised by the judge while handling his case violated the principles enshrined in Articles 2 and 61 of the Icelandic Constitution and Article 6 of the ECHR on the right to an impartial tribunal, but the latter was solely binding upon the Icelandic state as an international obligation. The Supreme Court stated that under the Icelandic judicial structure, judicial powers in district courts outside Reykjavik were in the hands of the town magistrates and district commissioners who served collaterally as chiefs of police. No specific facts had been demonstrated to establish the impartiality of the town magistrate or his deputy. The Court therefore dismissed Kristinsson's claim. ${ }^{5}$ Even though it did not refer to the ECHR in its reasoning, the Court clearly affirmed its position that incorporation of the convention was needed before it could be applied in domestic law. ${ }^{6}$

This, however, does not mean that Icelandic Courts do not consider unimplemented international obligations. Although international treaties do not have the same status as domestic law without being implemented by the Parliament, Icelandic courts seek to interpret the national law in accordance with international obligations insofar as possible. ${ }^{7}$ This is due to the principal rule that domestic law should be interpreted in accordance with international law insofar as possible. ${ }^{8}$ On the other hand, as a general rule, the domestic rules prevail if there is a conflict between the rules in question. ${ }^{9}$

Despite this, there are judgments in which it might be said that Icelandic Courts have gone quite a long way in interpreting domestic law in accordance with international law. At least a few judgments exists, especially in the 1990s, in which the result is not easily reconciled with the dualist principle. An example is Case No. 494/1991 of 6 June 1992. It was a criminal case against a defendant who could not speak Icelandic. He was therefore assisted during the proceedings by a court interpreter. According to relevant domestic rules at the time, the cost of the work of court interpreters was to be counted as legal costs and should therefore by imposed on the defendant, if convicted. However, the Supreme Court of Iceland stated that the

\footnotetext{
${ }^{4}$ See also Case No 273/1986 of 10 March 1987.

${ }^{5}$ It should be noted that the European Commission of Human Rights held unanimously that the proceedings were in breach of Article 6 of the Convention.

${ }^{6}$ Hannesson (2011), p. 434.

${ }^{7}$ See for instance Case No 177/1998 of 4 February 1990 and Case No 120/1989 of 9 January 1990.

${ }^{8}$ Björgvinsson (2020), p. 103.

${ }^{9}$ Thorarensen (2017), p. 343.
} 
relevant provisions should be interpreted in light of Article 6 of the ECHR and that the cost should therefore be paid by the State Treasury. ${ }^{10}$

In the Supreme Court's Case No 120/1989 of 9 January 1990, the Icelandic judicial structure was addressed again and a demand was made for the annulment of a district court judgment in a criminal case, on the grounds that the district court judge had not been impartial. However, this time the Court stated that changes had occurred in the particular Icelandic conditions that formed the background for the judicial structure. It then referred to the decisions of the ECHR Commission, which had concluded that the domestic proceedings in the aforementioned Kristinsson case had been in breach of Article 6 of the ECHR. The Commission had come to the conclusion that the fact that a judge in a criminal case was also a deputy chief was contrary to the aforementioned Article.

Many scholars have written about these judgments. ${ }^{11}$ Regarding Case No. 494/1991 of 6 June 1992, many have addressed the fact that, as the Icelandic provisions in question were incompatible with the ECHR, not only was the domestic law interpreted as consistent with the ECHR provisions but in fact the latter was given primacy over conflicting statutory domestic law. ${ }^{12}$ At the same time, it should be noted that the judgment was made in special circumstances, following the result from the European Commission on Human Rights regarding the Kristinsson Case No. $77 / 1985$ of 25 November 1985, which is discussed above. In other words, Icelandic Courts were under pressure regarding Iceland's obligations according to the Convention. ${ }^{13}$ In addition, the case was about defendants' constitutional rights in criminal cases and, therefore, about rights that were important from both international and national perspectives in relation to human rights. Finally, it should be mentioned that if a conflict occurs between domestic law and international law, Icelandic Courts will be more willing to apply interpretation more compatible with the international rule if the international commitment in question also affects interpretation of the Icelandic Constitution. ${ }^{14}$ This is especially the case with the ECHR, as described later in this article.

Most international treaties or agreements Iceland has ratified have not been incorporated into the national system. They are therefore not a part of the domestic law. Examples include the Universal Declaration of Human Rights from 10 December 1948, the International Covenant on Civil and Political Rights and the Covenant on Economic, Social and Cultural Rights from 16 December 1966, the International Convention on the Elimination of All Forms of Racial Discrimination from 21 December 1965 and the Convention on the Elimination of all Forms of Discrimination against Women from 18 December 1979. However, the legislator has on many

\footnotetext{
${ }^{10}$ Björgvinsson (2015), p. 96.

${ }^{11}$ See for example Björgvinsson (2015), p. 99; Arnardóttir (2018), p. 16; and Aðalsteinsson (1990), p. 22.

${ }^{12}$ See for example Björgvinsson (2015), p. 99; Arnardóttir (2018), p. 16; and Aðalsteinsson (1990), p. 22.

${ }^{13}$ Thorarensen (2019), p. 84.

${ }^{14}$ Thorarensen and Leifsson (2011), p. 34.
} 
occasions considered it necessary or desirable to incorporate treaties in order to give their provisions legal effect on the national level. ${ }^{15}$ This was done, for instance, with the two most important and influential treaties Iceland has entered: the ECHR and the EEA Agreement. Of all of Iceland's international obligations, these two treaties are without doubt the ones that have had most impact in Iceland. The following sections will discuss the status of these agreements in Icelandic law and their effect on court proceedings.

\section{The European Convention on Human Rights}

\subsection{The Status of ECHR in Icelandic Law}

Iceland signed the ECHR in 1953, but it did not have the force of law in Iceland until 1994, when it was incorporated and given the status of statutory law by the ECHR Act. ${ }^{16}$ Prior to the incorporation, Icelandic courts had stated that, as the ECHR did not have the status of law, courts would not rely on it if there was a conflict between the international obligation and national law. However, international obligations such as the ECHR were considered relevant when interpreting national rules governing similar rights. This could for example be seen in the Asmundsson case, ${ }^{17}$ where the Supreme Court took Article 8 of the ECHR into account when stating that the National Audit Office access to medical records was in breach of the principle of privacy. ${ }^{18}$

Since its incorporation, the ECHR has had the status of statutory law. This was clearly stated in the ASÍ case, ${ }^{19}$ where the District Court ruling, which was confirmed by the Supreme Court, said: 'The provisions of the ECHR do not enjoy the status of constitutional law.' However, there has been a tendency to consider it as having a special status in Icelandic law and Icelandic Courts tend to mention its provisions when referring to corresponding provisions of the Constitution. ${ }^{20}$ This is, firstly, because of the nature of the rights guaranteed in the treaty as fundamental rights. Secondly, it has been mentioned that the ECHR's status has to be seen in the light of its international background, and the principle of interpreting national law in accordance with international law. ${ }^{21}$ Thirdly, and perhaps most importantly, the ECHR has gained a special status in Icelandic law due to its direct connection to the Icelandic Constitution. ${ }^{22}$ One of the primary goals in the Constitutional changes in 1995 by the

\footnotetext{
${ }^{15}$ Björgvinsson (2015), p. 64.

${ }^{16}$ Act No. 62/1994.

${ }^{17}$ Case no. 5/1989 from 20 January 1989.

${ }^{18}$ Thorarensen (2017), pp. 345-346.

${ }^{19}$ Case No. 167/2002 from 14 November 2002.

${ }^{20}$ See for example Case No. 65/1999 from 30 September 1999 and Case No. 214/2014 from 20 November 2014.

${ }^{21}$ Björgvinsson (2008), p. 312.

${ }^{22}$ Björgvinsson (2017), p. 66.
} 
Constitutional Act No. 97/1995, which occurred shortly after the Act on the ECHR was implemented in Icelandic law, was to take into account the international obligations that Iceland had undergone through its membership in international human rights treaties and especially the ECHR. ${ }^{23}$ The human rights chapter of the Constitution was thus linked directly to ECHR's provisions. In the Explanatory Report to the law, it is also stated that although the ECHR should not have the status of Constitutional law, and that its provisions did not change the Constitution, it had to be borne in mind that the main reason for implementing it in domestic law had been to increase human rights protection in Iceland and that implementing it would lead the Courts to be more willing to interpret the Constitution in accordance with the Convention. ${ }^{24}$ Due to this, it has been said that the ECHR in fact has a special status in Icelandic.

\subsection{The Status of the Judgments of the European Court of Human Rights}

\subsubsection{Formal Status}

With regard to the effects of the judgments of the European Court of Human Rights (ECtHR) in Icelandic law, the principle of dualism applies. Article 2 of the Icelandic ECHR Act No. 62/1994 provides that the decisions of the European Commission of Human Rights, the ECtHR and the Committee of Ministers of the Council are not binding in Icelandic domestic law. In the Explanatory Report, it is also stated that the incorporation of the ECHR as statutory law does not automatically change the status of the decisions of the above-mentioned international institutions in the domestic system, since these decisions only concern the question of whether the Icelandic state has breached its obligations under the Convention. ${ }^{25}$ The decisions are therefore only binding under international public law, and they cannot overturn or invalidate domestic legislation or judgments of the national courts.

This reflects the firm position of the legislature that, despite the incorporation of ECHR, the principle of dualism still applies with regard to the decisions of these institutions. This principle position is further reiterated in the Explanatory Report, where it is emphasised that these decisions do not acquire binding legal effect in the national legal system in the same way as the text of the ECHR. It is up to the national courts and authorities to interpret the provisions of the ECHR independently. It is further reiterated that the incorporation does not involve any transfer of judicial power. The Council of Europe and the ECtHR only have the power to declare whether the ECHR has been breached, and their decisions do not annul domestic judgments. Moreover, it is for the Icelandic authorities, which operate on the basis of Icelandic

\footnotetext{
${ }^{23}$ Parliamentary Reports, A, pp. 2073 and 2077-2081.

${ }^{24}$ Parliamentary Reports, A, p. 2080.

${ }^{25}$ Parliamentary Reports A 1992-1993, Doc. No. 1160, pp. 5847-5939. Björgvinsson (2015) p. 144.
} 
law, to enforce the obligations established by the decisions of the ECtHR and other institutions. $^{26}$

An example of this understanding is Case No. 371/2010 of 22 September 2010, where the Supreme Court clearly stated that the incorporation of the ECHR into Icelandic law did not change the principal rule of dualism in terms of the relationship between international law and domestic law. Another example is the Jóhannesson and Jónsson case, ${ }^{27}$ in which the Supreme Court dismissed a case which had been reopened by a special committee on the grounds of a judgment in which the ECtHR had stated that a judgment of the Supreme Court had been in breach of the ne bis in idem rule. When dismissing the case, the Supreme Court stated that the rules did not include permission to reopen a case because of a judgment of the ECtHR which established a breach of the ECHR. It then said that, according to Article 2 of the ECHR Act, ${ }^{28}$ the judgments of the ECtHR were not binding in Icelandic law and that the Explanatory Report following the bill stated explicitly that despite the incorporation of the Convention, the dualism doctrine still applied.

\subsubsection{Indirect Binding Effect in Practice}

Despite a few judgments in 1990-2000, ${ }^{29}$ the implementation of the ECHR into Icelandic law did not seem to have the same effect on Constitutional interpretation as one might have expected. The Convention was indeed often mentioned in judgments of Icelandic Courts, but it did not seem to have much independent effect on the interpretation on the human rights provisions in the Constitution. ${ }^{30}$ Nor did Icelandic courts put much emphasis on the judgments of the ECtHR when establishing the rights derived from the Constitution regarding human rights. They mentioned the relevant Article of the ECHR, but direct references to ECtHR judgments were rare. However, in recent judgments, the influence of ECtHR case law has been more noticeable.

Today, Icelandic courts tend to refer to ECtHR case law more often than before. It is also clear that although the courts do not consider the ECtHR judgments to be formally binding, the ECtHR case law affects the interpretation of the Convention in Icelandic law as well as the human rights provisions of the Constitution. This has been increasingly noticeable since 2010 , and today it seems highly unlikely that a judgment is made in which the Constitution's human rights provisions are not put

\footnotetext{
${ }^{26}$ Björgvinsson (2015), pp. 144-145.

${ }^{27}$ Case No. 12/2018 from 21 May 2019.

${ }^{28}$ Act no. 62/1994.

${ }^{29}$ See, e.g., Case No. 167/2002 from 14 November 2002 and Case No 120/1989 from 9 January 1990. In the latter case, The Supreme Court of Iceland even interpreted a provision of the Constitution regarding eligibility of a judge in accordance with a provision of the Convention guaranteeing same rights. See also the interview with Róbert Ragnar Spanó ECHR justice in Kjarninn: https://kjarninn. is/frettir/2019-03-18-segir-tregdu-islenskra-domstola-ad-fylgja-domum-mde-vera-undanhaldi/.

${ }^{30}$ See, e.g., Case No. 475/2008 from 30 April 2009, Case No. 454/2009 from 11 March 2010 and Case No. 328/2008 from 5 March 2009.
} 
into context with ECHR's provisions and the rules the ECtHR has laid down in its practice. Three examples are Case No. 215/2014 of 18 December 2014, Case No. 467/2015 of 13 August 2015 and Case No. 367/2016 of 30 March 2017. In the latter case, Article 71 of the Constitution on freedom of privacy was interpreted in accordance with comparable provision of Article 8 of the ECHR. With regard to the interpretation of Article 71 of the Icelandic Constitution on freedom of privacy, the Supreme Court held, after referring to the Case of Paradiso and Campanelli v. Italy of 24 January 2017 regarding family relationship and children born to surrogate mothers:

According to Article 71 (1) everyone should enjoy freedom of privacy and family. Among things that have to be taken into account when interpreting the provision is how The European Court of Human Rights has interpreted a parallel provision in Article 8 (1) of the European Convention on Human Rights. ${ }^{31}$

This case is an example of how Icelandic Courts have become more willing to take into account the case law of the Court in Strasbourg and demonstrates that the ECHR is in fact an integral element when it comes to interpreting the human rights provisions of the Constitution. ${ }^{32}$

Another example is Case No. 283/2016 of 21 September 2017, in which the Supreme Court departed from previous judgments because of new judgments from the European Court of Human Rights regarding the rule of ne bis in idem. ${ }^{33}$ In other words, the Strasbourg Court's judgments were considered de facto 'binding', despite the wording of Article 2 of law no. 62/1994. In addition, it might be mentioned that the case was decided by seven Supreme Court justices, something which is only done in particularly important cases. ${ }^{34}$ The Appeal Court (Landsréttur) judgment in Case No. 209/2018 of 9 March 2018 is also a good example, as the Landsréttur interpreted provisions on cost insurance in a new way because of a certain ECtHR judgment regarding access to justice according to Article 6 of the ECHR.

In all of these cases, Icelandic Courts have taken a step further in interpreting the Icelandic Constitutional provisions on human rights in accordance with the ECHR and ECtHR case law. In other words, ECtHR case law was decisive in interpreting the interplay of the constitution and general provisions. ${ }^{35}$

In light of this, and despite what has previously been said about the formal status of the ECHR and ECtHR judgments in Icelandic law, it is safe to say that the effect of the ECtHR on court practice in Iceland is considerable, at least to the extent that Icelandic provisions are in parallel with those of the ECHR. If the ECtHR has interpreted the Convention in one of its rulings, Icelandic Courts will follow that interpretation insofar as possible when interpreting the human rights provisions of the Icelandic Constitution. This applies at least when the provision in the Constitution

\footnotetext{
${ }^{31}$ Author's translation.

${ }^{32}$ Spanó: Lunch meeting in Nauthóll, 2 November 2018.

${ }^{33}$ Spanó: Lunch meeting in Nauthóll, 2 November 2018.

${ }^{34}$ Arnardóttir (2018), p. 21.

${ }^{35}$ Interview with Róbert Ragnar Spanó, ECHR justice in Kjarninn.: https://kjarninn.is/frettir/201903-18-segir-tregdu-islenskra-domstola-ad-fylgja-domum-mde-vera-undanhaldi/.
} 
mirrors a provision in the ECHR, and guard the same rights as the ECHR. This was specially stated in the abovementioned Case No. 371/2010 of 22 September 2010, in which the Supreme Court of Iceland emphasised that Icelandic courts would consider ECtHR's decisions when interpreting the ECHR when applied as a part of the domestic law. It is also clear that the Supreme Court will, when examining each case, consider whether the national authorities have sufficiently taken into account the principles flowing from its judgments. ${ }^{36}$

In relation to the effects of the ECHR on Icelandic Court procedures, it might also be mentioned that a new Court of Appeal, Landsréttur, started its work in Iceland on 1 January 2018, replacing the former two-tiered system with a three-tiered system. One of the aims of the establishment of this court, which is a second instance court handling cases between the District Courts and the Supreme Court of Iceland, was to fulfil ECHR obligations in relation to review before a higher court. At the moment of writing, a case concerning the appointment of judges at the new court is still pending before the Grand Chamber of the ECtHR. The case concerns the claim of Mr. A, who was convicted at a district court of driving without a valid license and of being under the influence of narcotics. He appealed the decision to the new Court of Appeal, in which one of the judges was Ms. E, one of the candidates whom the Minister of Justice had appointed to the court even though she was not among the 15 candidates initially selected by a special evaluation committee. By a judgment of 23 March 2018, the Court of Appeal upheld the District Court's judgment on the merits and that judgment was appealed to the Supreme Court. Before the Supreme Court the applicant insisted that the Court of Appeal's judgment be quashed and the case be remitted for retrial. His claims were based, inter alia, on the ground that the appointment of Ms. E. had violated the general principle that authorities should appoint the most qualified candidate for office. Therefore, Ms. E's appointment had not been in accordance with the law as required by Article 59 of the Constitution and Article 6 of the ECHR. This had also resulted in Mr. A not enjoying a fair trial before an independent and impartial tribunal as stipulated in Article 70 of the Constitution and Article 6 of the ECHR. By a judgment of 24 May 2018, the Supreme Court rejected the applicant's claims and upheld the judgment of the Court of Appeal. With regard to the complaint concerning the appointment of Ms. E, the Supreme Court held that although the appointment of the judges had not been fully in accordance with law, it had been a breach that did not have significance. The fifteen judges had been appointed in accordance with formal procedural rules of the Judiciary Act, ${ }^{37}$ and it could not therefore be said that rulings of the Court of Appeal, which Ms. E delivered along with others, were on that ground a 'dead letter' as claimed by Mr. A. When it was assessed whether Mr. A had not enjoyed the right to a fair trial before an independent and impartial tribunal according to the Constitution and Article 6 of the ECHR, account had to be taken of the fact that the appointment of all fifteen of the judges had become a reality upon the signing of their letters of appointment and that they all fulfilled the requirement of the Judiciary Act to be appointed in the light of

\footnotetext{
${ }^{36}$ See, e.g., Case No. 33401/02 from 9 June 2009.

${ }^{37}$ Act No. 50/2016.
} 
their professional experience and legal knowledge. They had independence in their judicial work but also a duty to perform it under their own responsibility, and the Constitution precluded them from being discharged except with judicial decision. Therefore, in spite of the flaws in the procedure by the Minister of Justice, it could not be said that there was sufficient reason to justifiably doubt that Mr. A had enjoyed a fair trial before independent and impartial judges. That decision was then brought before the European Court of Human Rights. In its Chamber judgment of 12 March 2019, the ECtHR held that there had been a violation of Article 6 as the bench at Landsréttur had not been established by law. At the time of this writing, that judgment is now under consideration at the Grand Chamber.

\section{The EEA Agreement}

\subsection{The Status of the Agreement in Icelandic Law}

As Iceland is not a member of the European Union (EU), its relation to the EU is mainly based on the EEA Agreement, which came into effect in 1994 and was incorporated by the EEA ACT. ${ }^{38}$ The EEA Agreement unites the EU member states and the three EFTA/EEA states (Iceland, Liechtenstein and Norway) into a single market governed by the same basic rules. EEA law originates from EU law. As a matter of principle, the EU law rules concerning the single market have been transposed and are being transposed to the EEA legal order. According to the EEA agreement, the EFTA States are obliged to implement and apply EU legal acts that have been incorporated into the Agreement by the EEA Joint Committee.

All the relevant Internal Market legislation is integrated into the EEA Agreement so that it applies throughout the whole of the EEA. The core of the rules relates to the free movement of goods, capital, services and persons throughout the 31 EEA States - the 28 EU States and 3 of the EFTA States. In addition, the EEA Agreement covers horizontal areas such as social policy, consumer protection, environment, company law, statistics, tourism and culture. However, the common policies in the fields of agriculture, fisheries, taxation, foreign trade and currency are not part of EEA law.

\subsection{The EFTA Surveillance Authority and the EFTA Court}

The successful operation of the EEA depends upon uniform implementation and application of the common rules in all EEA States. The EFTA Surveillance Authority (ESA) monitors compliance with the EEA Agreement in the EFTA States in the same way that the EU Commission does in the EU Member States. In addition, the EFTA Court operates in parallel to the Court of Justice of the European Union, with a

${ }^{38}$ Act No. 2/1993. 
jurisdiction with regard to EFTA States. The Court is mainly competent to deal with infringement actions brought by the ESA against an EFTA State with regard to the implementation, application or interpretation of EEA law rules, for giving advisory opinions to courts in EFTA States on the interpretation of EEA rules and for appeals concerning decisions made by the ESA. ${ }^{39}$

To this end, a two-pillar system of supervision has been devised: the EU Member States are monitored by the EU Commission and the EFTA States are party to the EEA Agreement by the ESA.

\subsection{Protocol 35 of the EEA Agreement}

From Article 7 EEA, it follows that EU secondary legislation will not become a part of the national legal order until specific measures have been taken to implement it. The direct applicability and direct effect of secondary legislation, including EU regulations, are therefore dependent on it having been incorporated in the national legal order in accordance with constitutional and other domestic legal standards. This clearly corresponds to the principle of dualism. ${ }^{40}$

However, the Icelandic state is bound by Protocol 35 of the EEA Agreement, whose aim is to help achieve a homogeneous EEA without requiring the states to transfer legislative powers to any institution of the EEA. The EFTA Court has also stated that national Courts need to interpret national law in accordance with EEA rules. ${ }^{41}$ The Sole Article of Protocol 35 says:

For cases of possible conflicts between implemented EEA rules and other statutory provisions, the EFTA States undertake to introduce, if necessary, a statutory provision to the effect that EEA rules prevail in these cases. ${ }^{42}$

Article 3 of the EEA Act in Iceland was meant to implement this rule. It says that domestic law and regulations shall be interpreted, to the extent appropriate, in accordance with the EEA Agreement and the regulations incorporated into the agreement. Accordingly Iceland has adopted a specific rule providing for consistent or friendly interpretation in line with the EEA commitments. However no clear-cut primacy rule has been implemented as would seem to be the requirement by the wording of Protocol 35. ${ }^{43}$ It is also clear that article 35 only regulates the situation in which an implemented EEA rule conflicts with another statutory rule. It does not regulate the situation in which an EEA rule is not implemented.

It has therefore been debated whether Article 3 really provides for the primacy of EEA law as required by Protocol $35{ }^{44}$ The explanatory notes refer to the Icelandic

\footnotetext{
${ }^{39} \mathrm{https}: / /$ eftacourt.int/the-court/introduction/.

${ }^{40}$ Björgvinsson (2015), p. 70.

${ }^{41}$ Hreinsson (2014), p. 274.

${ }^{42}$ Article of Protocol 35.

${ }^{43}$ Björgvinsson (2015), p. 70.

${ }^{44}$ Pétursson (2017), p. 207; Björgvinsson (2006), p. 132; and Einarsdóttir (2007), pp. 25-35.
} 
legal tradition that domestic law shall be interpreted in line with international obligations to the extent possible. It also refers to the legal tradition that law of the status of lex specialis prevails over other law and that an EEA rule would often be considered a rule of that type. The explanatory note then mentions that Article 3 provides that domestic law arriving from the EEA agreement will in general be considered a lex specialis rule with regard to younger law in conflict. The latter will therefore not prevail unless especially decided by the legislature. ${ }^{45}$ However, this understanding is not in accordance with the direct wording of Article 3.

\subsection{Article 3 in Court Practice}

The first time the Icelandic Supreme Court interpreted Article 3 was in Case No. 477/2002 from 15 May 2003. Mr. E claimed that the State had breached Article 14 of the EEA Agreement by demanding higher taxes on books in foreign languages $(24,5 \%)$ than on Icelandic books (14\%). The Court referred to the explanatory notes previously mentioned and interpreted Article 14 of the EEA Agreement to be lex specialis that should prevail over the older tax rules in question.

This judgment led many to believe that the Supreme Court would interpret Article 3 in a way consistent with what was stated in the explanatory notes regarding EEA rules as a lex specialis. ${ }^{46}$ However, another approach can be found in more recent judgments, where it is stated that, despite Article 3 and the fact that domestic law shall be interpreted in line with international obligations, an interpretation of any kind will not exceed the wording of written statutory law. In other words, an interpretation contra legem is not permitted.

This was for example stated in Case No. 79/2010 of 9 December 2010. The case concerned a vendor's and importer's liability for damages caused by candy it sold and imported. Iceland had implemented a directive on a product liability (85/373/EB) with Law No. 21/1991, but in addition to the manufacturer's and importer's liability the Icelandic provision made the distributor responsible as well. This went beyond the directive in question, and at the time the European Court of Justice had already determined that a similar provision in Danish law was not in accordance with the directive. Nonetheless, the Supreme Court of Iceland refused to set the wording of the Icelandic provision aside because of Article 3. It said:

Article 3 of law No. 2/1993 states that statutes and regulations shall be interpreted in so far as appropriate in accordance with the EEA to accord with the EEA Agreement and the rules based thereon. According to this, the wording of domestic law will insofar as possible be interpreted in line with the EEA rules. It will not, however, lead to a result where the wording of domestic law is ignored. ${ }^{47}$

\footnotetext{
${ }^{45}$ Parliamentary Reports, A 1991-1992, p. 5922.

${ }^{46}$ See Líndal and Magnússon (2011), p. 176; Tynes (2002), pp. 494-495; and Pétursson (2017), p. 209.

${ }^{47}$ The law in question, Act No. $25 / 1991$ on Product Liability, was subsequently amended in accordance with the EEA-rule and is now Act No. 3/2014.
} 
The Supreme Court's Case No. 92/2013 of 13 October 2014 is another example where a clear and precise wording of domestic legislation stands in the way of EEA conformity. In this case, Mr. G wanted a tax decision deemed invalid, because he did not get a tax relief that he would have gotten if he had lived in Iceland instead of Denmark at a certain time. The Supreme Court concluded that Iceland had not implemented the relevant directive (the Citizenship Directive) $)^{48}$ sufficiently. Therefore, Icelandic tax authorities could not have relied on the EEA rule in question in their decision because it was contrary to the clear and precise wording of a domestic rule. This is in accordance with the fact that Article 35 of the EEA Agreement does not regulate non-implementation. ${ }^{49}$

It follows that if the provisions of national law cannot be interpreted in accordance with the provisions of the EEA rule, the Icelandic law should apply, provided that the traditional Icelandic legal explanatory rules do not lead to a different conclusion. In other words, the implemented EEA rules will not prevail. ${ }^{50}$

On the other hand, if the wording of the Icelandic provision in question is in line with EEA law, Icelandic courts will seek to conduct EEA-consistent interpretation. The Supreme Court's Case No. 169/2011 from 17 January 2013 is a good example, as the Supreme Court interpreted the meaning of 'deposit' in accordance with the EFTA Court's advisory opinion on the matter. ${ }^{51}$ Another example is the WowAir case, ${ }^{52}$ in which the flight company WowAir claimed that another company, Icelandair, had a competitive advantage regarding time slots at the Keflavik airport. In reaching a conclusion, Icelandic courts interpreted domestic legislation in line with EEA law and in that connection mentioned the interpretation rule in Article 3.

According to the aforementioned judgments, it is clear that clear and precise wording of a domestic legislation prevents EEA-consistent interpretation if the provisions in question are in conflict. Recent judgments seem to exclude the possibility of a priority effect of implemented EEA rules when in conflict with younger domestic law. The Supreme Court seems to think of Article 3 as an interpretative method to be used when interpreting law arising from the EEA Agreement rather than as a rule prescribing the priority of implemented EEA rules. ${ }^{53}$ Domestic law is only interpreted in accordance with EEA law to the extent possible within the wording of the national law. This is in line with the wording of Article 3 of Law No. 2/1993, although it is clear that the provision does not meet the obligations arising from Protocol 35. ${ }^{54}$ This does not mean that individuals have no remedies to rely on in terms of wrongful

\footnotetext{
${ }^{48}$ Directive 2004/38/EC of the European Parliament and of the Council of 29 April 2004 O.J. L158/77 (2004).

${ }^{49}$ See also Case No. 160/2015 from 13 May 2015, Case No. 243/2015 from 26 November 2015 and Supreme Court Case No. 10/2013 from 24 January 2013.

${ }^{50}$ Einarsdóttir and Stefánsson (2020), p. 350.

${ }^{51}$ Case No. E-17/11, EFTA Ct. Rep. 2012s. 916.

${ }^{52}$ Case No. 95/2015 from 18 February 2015.

${ }^{53}$ Pétursson (2017), p. 207; Björgvinsson (2006), p. 132; and Einarsdóttir (2007), pp. 25-35.

${ }^{54}$ Pétursson (2017), p. 223.
} 
implementation, as they may seek damages on that ground before Icelandic Courts. ${ }^{55}$ The ESA can also bring an infringement action against the Icelandic State before the EFTA Court with regard to the implementation. ${ }^{56}$ In light of this, it has been pointed out that the application of properly implemented EEA rules in Iceland hardly meets the requirement of Protocol 35, as the EEA rules do not have priority over incompatible Icelandic law. In light of the Supreme Court's ruling on the subject and the wording of Article 3 of the EEA Act, it seems clear that in order to fulfil that obligation it could be necessary to implement Protocol 35 in a way more in line with the aim of that protocol. ${ }^{57}$

\section{Summary}

It is safe to say that the relationship between Icelandic Courts and European law has improved significantly in recent years. Although some judgments may be indeed be found in which the Courts have been a bit hesitant in this regard, this only seems to be the case when the clear wording of the Icelandic provision in question does not leave room for the interpretation required by the international rule. Overall, numerous judgments show clear efforts to interpret domestic law in accordance with international law obligations, especially with regard to the EEA agreement and the ECHR. To some extent, the latter seems, at least in recent years, to have had a more direct effect on the Court practice, as Icelandic courts seem to be willing to give the human rights provisions of the Icelandic Constitution the same meaning as derived from the ECHR according to the ECtHR's case law. This is, among other things, due to the relationship between the Icelandic ECHR Act and the human rights chapter of the Icelandic Constitution, as addressed in Sect. 3. The EEA agreement in Icelandic law differs from ECHR, as the regulatory framework resulting from the contract is more complicated and complex, and the implementation into national law and the wording of the national rule following the implementation are not always exactly the same as laid down by the European law. According to a few judgments of the Supreme Court, that can be a problem, as the wording of a domestic legislation can prevent EEA-consistent interpretation if the provisions in question are in conflict.

\section{References}

Aðalsteinsson R (1990) Alpjóðlegir mannréttindasáttmálar og íslenskur landsréttur. Tímarit Lögfræðinga 1:3-27

Arnardóttir O (2018) Nálægðarregla, svigrúm til mats og samband Mannréttindadómstóls Evrópu við landsrétt. Bókaútgáfan CODEX, Reykjavík

\footnotetext{
${ }^{55}$ See, e.g., Case No. 236/1999 from 16 December 1999.

${ }^{56}$ Pétursson (2017), p. 222.

${ }^{57}$ Einarsdóttir and Stefánsson (2020), p. 353.
} 
Björgvinsson D (2006). EES-réttur og landsréttur. Bókaútgáfan CODEX, Reykjavík

Björgvinsson D (2008) Lögskýringar. Kenningar, aðferðir og sjónarmið við skýringu og beitingu laga. Reykjavík

Björgvinsson D (2014) Staða dóma Mannréttindadómstóls Evrópu í íslenskum landsrétti. Tímarit Lögréttu 1:23-42

Björgvinsson D (2015) The intersection of international law and domestic law-a theoretical and practical analysis. Edward Elgar Pub, Cheltenham

Björgvinsson D (2016) The effect of the judgments of the ECtHR before the national courts-a nordic approach? Nord J Int Law 85:303-321

Björgvinsson D (2017) Mannréttindasáttmáli Evrópu. Meginatriði, skýring og beiting. Mannréttindasamningar Sameinuðu pjóðanna. Meginreglur, framkvæmd og áhrif á íslenskan rétt

Björgvinsson D (2020) Pjóđaréttur og landsréttur í dómum Hæstaréttar. Hæstiréttur í hundrað ár, pp 95-132

Einarsdóttir M (2007) Forgangsáhrif Réttilega Innleiddra EES-Reglna. Tímarit Lögréttu 1:29-34

Einarsdóttir M and Stefánsson S (2020) Beiting innlendra EES-reglna í íslenskum rétti íljósi bókunar 35. Hæstiréttur í hundrað ár, pp 341-357

Hannesson Ó (2011) The status of non-implemented EEA law in Iceland: lessons from the judicial reactions of the supreme court to international law. Nordic J Int Law 80:425-458

Hreinsson P (2014) Samræmd EES-Túlkun. Tímarit Lögfræðinga 3:273-307

Líndal S, Magnýsson S (2011) Réttarkerfi Evrópusambandsins og Evrópska efnahagssvæðisins. Hið íslenska bókmenntafélag, Reykjavík

Pétursson G (2017) Forgangur EES-reglna. Hvað er að frétta af bókun 35?. Fullveldi í 99 ár. Safn ritgerða til heiðurs dr. Davíð Pór Björgvinssyni sextugum. Reykjavík

Thorarensen B (2017) Staða og áhrif Mannréttindasamninga Sameinuðu pjóðanna í íslenskum rétti. Mannréttindasamningar Sameinuðu bjóðanna. Meginreglur, framkvæmd og áhrif á íslenskan rétt, pp 339-381

Thorarensen B (2019). Stjórnskipunarréttur - Mannréttindi. Bókaútgáfan Codex, Reykjavík

Tryggvadóttir R, Ingadóttir P.: Online article, https://www.nyulawglobal.org/globalex/Iceland1. html

Thorarensen B and Leifsson P (2011) Pjóðaréttur. Bókaútgáfan Codex, Reykjaví

Tynes D (2002) Ys og pys út af engu? Hugleiðingar um bókun 35 við samninginn um Evrópska efnahagssvæðið. Úlfljótur 3:473-496

Wallace R (2005) International law, 5th edn. Sweet \& Maxwell, London

Open Access This chapter is licensed under the terms of the Creative Commons Attribution 4.0 International License (http://creativecommons.org/licenses/by/4.0/), which permits use, sharing, adaptation, distribution and reproduction in any medium or format, as long as you give appropriate credit to the original author(s) and the source, provide a link to the Creative Commons license and indicate if changes were made.

The images or other third party material in this chapter are included in the chapter's Creative Commons license, unless indicated otherwise in a credit line to the material. If material is not included in the chapter's Creative Commons license and your intended use is not permitted by statutory regulation or exceeds the permitted use, you will need to obtain permission directly from the copyright holder.

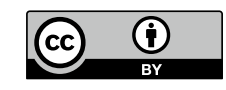

